\title{
The Russian Foreign Policy towards Syria after the Arab Spring
}

\author{
Nesma Tarek \\ Political Science, The British University in Egypt, Cairo, Egypt \\ Email: Nesma.tarek.228@gmail.com
}

How to cite this paper: Tarek, N. (2021) The Russian Foreign Policy towards Syria after the Arab Spring. Open Access Library Journal, 8: e7976.

https://doi.org/10.4236/oalib.1107976

Received: September 17, 2021

Accepted: October 25, 2021

Published: October 28, 2021

Copyright $\odot 2021$ by author(s) and Open Access Library Inc.

This work is licensed under the Creative Commons Attribution International License (CC BY 4.0).

http://creativecommons.org/licenses/by/4.0/

\begin{abstract}
The purpose of this research is to discuss why did Russia intervene in Syria after the Arab spring. The aim of the research is to show the main reasons for the Russian involvement in the Middle East after the Arab spring while it was not intervened in the Middle East in the 2000s. This research argues that Russia intervened in Syria after the Arab spring in order to secure its interests in the Middle East which was threatened by the United States. Russia felt insecure due to the American policies which threatened the Russian interests. This research focuses on the uprising in Syria and how it led to challenge the hegemony of the US. This research is divided into four chapters. The first chapter includes the literature review regarding the Russian intervention in Syria and it discusses the main assumptions of the power transition theory. The second chapter discusses the global patterns of interaction between Russia and the west. In addition, it discusses how the process of power transition started. The third chapter discusses the main indicators for the transition on the regional level. The fourth chapter includes conclusion of the research through analyzing the Russian intervention in the Middle East after the Arab Spring in terms of the power transition theory and the expected scenarios for the future regarding the power transition.
\end{abstract}

\section{Subject Areas}

International Relations

\section{Keywords}

Russia, United States, China, Power Transition Theory, Middle East

\section{Introduction}

The Russian foreign policy had always been fierce to seek power in order to pro- 
tect its interests. This can be shown during the cold war and how Russia was trying to achieve its dominance and presence on the international system as a great power in order to defend its agenda. After the collapse of the Soviet Union, the idea of reviving it did not vanish. Thus, Russia was trying to take the advantage of any opportunity in order to return on the international system.

The Arab spring was an opportunity for Russia in order to play the game of great power. This can be shown its intervention in the Middle East especially in Syria. The Russian intervention in Syria represents an important step in enhancing its role internationally through portraying itself as a mediator "Russia has latched on to turmoil in the Middle East, highlighting what it believes are Western policy failures and unreliability, to present itself as a reliable alternative to traditional Middle Eastern leaders" [1].

\subsection{Research Statement Problem}

The research problem lies in discussing the Russian foreign policy towards Syria after the Arab Spring. This can be shown through the research question which is "why did Russia intervene in Syria after the Arab spring?" This research argues that Russia had felt threatened to the extent that it was dissatisfied by the US policies. Thus, Russia intervened in Syria to secure its interests and undermine the role of the US which ultimately would enhance its status. Therefore, the research gap can be shown through two main elements which are; power politics that Russia always seeks in order to improve its status in the international system and the interventionist policies of the U.S. since the end of Cold War that led to the regime change which represented a threat on the stability of Russian regime. Hence, the significance of the research is to analyze and highlight how the Russian security was provoked by the US role in Syria which led Russia to challenge this status quo.

\subsection{Literature Review}

The main aim of Russia is to become an important player in the international system. This can be shown during the Cold War and its race with the United States for it to become the hegemonic power. Although Russia did not achieve its domination during the Cold War, it was working on achieving it. Syria was the opportunity that Russia took in order to achieve its influence in the Middle East and challenge the domination of the US. The Russian intervention in Syria can be explained through three factors which are; political, economic and, security.

The political factors can be shown through different point of views. Malashenko [2] argued that the Russian intervention in Syria was to revive the idea of the Soviet. The aim of Russia was to return back on the international system as a great power "Putin's attempts to shore up Russian influence in the Middle East were motivated by a combination of nostalgia for the legacy of Soviet influence and strategic national interests" [2]. Also, Borshchevskaya (2013) [3] argued that Putin has always seeking to return Russia as a great power in order to have more 
influence in the Middle East to counter the American influence in the region. Hence, the intervention in Syria represented the starting point for Russia to increase its influence in the region through the strategic location of Syria. Dyner [4] argued that the Russian intervention in Syria strengthened the position of Russia as a negotiator in the future of Syria which can be shown through its involvement in Astana process which resulted in electing committee under the supervision of the UN to work on establishing new Syrian constitution. Moreover, Polyakova [5] argued that the political instability in Russia which was obvious by the protests in Ukraine led to the intervention in Syria. As a result of increasing tension between Russia and the U.S. because of the response of the U.S. to the Russian invasion in Ukraine and the Russian policies towards Crimea, Russia was further encouraged to intervene in Syria. Wakim [6] argued that the Russian intervention in Syria was because of the Russian fear of waging a proxy war in Syria against it and its allies such as Iran and China by the U.S. and its European allies which threats its trade routes and its national security. Beccaro and Maass [7] stated that Russia took advantage of changing the balance of power in the Mediterranean in order to increase its military and political influence in the region through its intervention in Syria.

On the other hand, the Russian intervention in Syria was criticized by some authors. Although Polyakova [5] argued that the Russian intervention was because of the political instability in Russian and its tension with the United States, Russia can be involved in a fog war as it is difficult for Russia to guarantee clean withdraw from Syria without leaving Assad at risk. Also, Zvyagelskaya [8] argued the cooperation of Russia with Iran will strengthen Iran which goes against the objectives of the Arab regimes.

Regarding the economic factors, Saradzhyan [9] [10] stated that Russia intervened in Syria in order to achieve its economic diversification by getting access to the Syrian markets. The access to the Syrian markets represents in maintaining the relation between them in buying the Russian arms. [11] argued that the economic crisis that Russia had faced whether as a result of the drop of the oil prices internationally or because of the sanction that was imposed on it after the annexation of Crimea, represented a pressure on the Russian economy. As a result, Russia directed its trade to the Middle East generally and specifically to Syria. In addition, Szénási [12] argued that the Russian intervention in Syria was to secure its gas exports as Syria represents a mutual point for Russia and the U.S. in supplying gas to Europe. Furthermore, Borshchevskaya (2013) stated that the fall of the Libyan regime led to huge losses in the weapon contracts which made Russia afraid to repeat this again in Syria "From 2007 to 2010, the Russian arms sales to Syria reached $\$ 4.7$ billion, more than twice the figure for the previous four years, according to the Congressional Research Service. More broadly, Russia is now the world's second-largest arms exporter after the United States" [3]. Hill [13] argued that Russia was afraid of the fall of the Syrian regime as Syria represents access to the Russian naval base in Tartus. Thus, the Russian military 
exports to Syria represent an important element in making the Syrian regime dependent on Russia which guarantees the Russian presence in Tartus.

The Russian intervention was criticized as it made the Russian economic conditions get worse. Nizameddin (2016) argued that the Russian intervention in Syria did not improve the Russian economy which can be shown through sanctions that were imposed on Putin as a result of his foreign policy towards Syria "The daily cost for the military intervention in Syria is US\$4 billion which represents a pressure on the Russian economy". With Russia's economy declining in 2015 by about $3.8 \%$, an inflation rate rising to $15 \%$ and wages coming under pressure along with the ruble, which fell by $50 \%$ between 2014 and 2015 [14].

Regarding the last factor which is related to security. Zvyagelskaya [8] stated that the core aim of Russia is to maintain the unity of Syria as the unity of Syria would secure the presence of Russia in the region especially its naval base in Tarsus. Moreover, Mohseni [15] argued that Russia intervened in Syria in order to protect its national security which represented in containing the threats that are imposed by the Islamic terrorist groups such as ISIS in Syria. Techau [16] argued Russia was afraid that the Islamic groups could reach its lands. Thus, fighting these Islamic groups is considered a way of protecting the domestic security of Russia.

The literature review can be criticized in terms of not linking the three factors that led to the Russian intervention in Syria. It discussed each factor separately. The link among these factors represents a momentum for the transition process. Each factor plays a role in the process of transition. Regarding the political and security factors, it can be linked to the satisfaction of the states on the hegemon power. On the other hand, the economic factors play an essential role in the accumulation of resources which lead to challenge the dominant power. Hence, path the way for the transition.

\subsection{System Level of Analysis}

The system level of analysis can be used to discuss the Russian intervention in Syria by explaining how the authority of states is organized in the international system. The system level of analysis mainly includes how the international system works and how states seek their survival as a result of the anarchic structure "With many sovereign states, with no system of law enforceable among them, with each state judging its grievances and ambition according to the dictates of its own reason or desire-conflict, sometimes leading to war, is bound to occur" [17]. The system level of analysis mainly focuses on the external restraints in foreign policy. These restraints can be divided based on the behavior of states which is related to the characteristics of the structural system, its norms, and its power relationships.

This research focuses on the structural restraints which refer to the level of interactions among states. It includes two main elements; the organization of 
authority in the international system and the scope of interactions among states in the international system. Regarding the organization of authority in the international system which refers to the enforcement of rules by the structure of authority "The structure of authority for making and enforcing rules, for allocating assets, and for conducting other authoritative tasks in a system can range from hierarchical (vertical) to anarchical (horizontal)" [18]. It describes the international system as a state-centric which refers to the system as anarchic. Furthermore, it shows how the distribution of power can affect the foreign policy of states. It divided the international system based on polarity as unipolar system which is the dominant power on the international system that controls and puts the rules of the game, bipolar which refers to the race between two states in order to dominate the system and how each state tries to get rid of the other and the last was which is multipolar system refers to the distribution of power among states which leads to the balance of power. Regarding the scope of interaction, it refers to the interaction among states. This interaction can be through the economic interdependence among states which makes each state tries to keep its relation with other states in order to maintain the interdependence between them [18].

\subsection{Theoretical Framework}

The Russian intervention in Syria can be explained through the power transition theory. Power transition theory argues that the international system is based on a hierarchy which is related to the satisfaction or dissatisfaction of states as a measure for the status quo. It classifies the international system in terms of hierarchical power. The paper examines how power transition theory can be applied to the Russian foreign policy after the Arab Spring towards the Middle East generally and Syria specifically.

Power transition theory was first defined by Organski in the 1950s. Organski described the international system as based on hierarchy. In his point of view, the result of the hierarchal nature of the international system leads to the emergence of a dominant power which puts and controls the role of the game. He emphasized the importance of the satisfaction of the states about the dominant power as a tool to achieve stability and maintain the status quo of the international system. He also emphasized the relation between hierarchy, status quo, and power in the international system [19].

The issue of the hierarchy of the international system lies in the distribution of power in the international system among states. Orgnski and Kugler classified the international system into the dominant nation, great power, middle power, and small power. For Orgnski and Kugler, the dominant power is the one that controls the rules of the game. The main aim for the dominant power is to maintain its domination and presence in the international system via achieving satisfaction for the rest of the states [20].

Thus, the dominant power tries to achieve satisfaction which is the second 
main assumption of power transition theory. According to Orgnski, if the great powers are not satisfied with the status quo, they must have the qualifications which are economic and military powers that help them to challenge the dominant power and change the balance of power. Regarding the middle and small states, most of them are not satisfied with the dominant power but they do not have the power and the resources to challenge it. For Orgnski and Kugler, it is difficult to achieve satisfaction for all states even if the great powers are satisfied with the dominant power, the middle and small powers are not completely satisfied "Whenever the dissatisfied nations are weak, however, they cannot (in isolation or by combining with each other) pose a threat to the dominant nation and the coalition supporting the international order" [20].

The dissatisfaction of great powers leads to wars as great powers want to have an effective place in the international system and want to control the rules of game "The fundamental problem that sets the whole system sliding almost irretrievably toward war is the differences in rates of growth among the great powers and, of particular importance, the differences in rates between the dominant nation and the challenger that permit the latter to overtake former in power" [21].

Power transition theory can be applied to the Russian intervention in Syria through its two main assumptions. The first assumption which refers to the hierarchy of the international system and the degree of satisfaction or dissatisfaction of states on the hegemonic power which can be applied to Russia by its dissatisfaction about the policies of the United States. As the US represents the hegemonic power, Russia wants to revive its presence on the international system as a great power through challenging the US. Regarding the second assumption which is related to the number of resources in order to challenge the hegemonic power. This can be applied to Russia by referring to its revenues and its economic status in 2000s. It shows how the economic status of Russia was improved especially after the massive losses in the Cold War. This can illustrate why Russia became dissatisfied about the American policies after the Arab spring although there were confrontations between them in the 2000s, Russia did not challenge it during that time. Thus, the Arab spring was an opportunity for Russia to play the game of great power again after improving its economic status.

\subsection{Methodology}

This research will be based on deductive research as it focuses on specifying the theory which is the power transition theory, then applies it on the case which is the Russian intervention in Syria through collecting the data about it. The research will conduct content analysis by referring to the speeches of president $\mathrm{Pu}$ tin and Bush before the Arab spring during the 2000s and after the Arab spring. This research uses secondary resources as it will analyze the data of other researches and the existing date such as academic journals, books, and academic articles. The research will also refer to original resources such as reports. 


\subsection{The Division}

The research divides into four chapters. The first chapter discusses the literature review which includes the main factors of the Russian intervention in Syria which are political, economic and security factors. Furthermore, the chapter discusses the theoretical framework of power transition theory and how it can be applied to the Russian intervention in Syria. It includes two main assumptions. The first assumption is related to the hierarchy of the system and the degree of satisfaction or dissatisfaction of states about the hegemonic power. The second assumption discusses the number of resources in order to challenge the hegemonic power. The second chapter will discuss the global patterns of interaction between Russia and the west and Russia and the U.S. before the Arab Spring in the context of power transition theory which represented in Russia-Belarus energy dispute, Russia-Ukraine gas dispute, South Ossetia war with Georgia, and the second Chechen war. The third chapter will discuss the presence of Russia on the regional level which represented in the Middle East after the Arab spring in Tunisia, Egypt, Libya, Bahrain, and Yemen, then apply the power transition theory on the Russian intervention in Syria. In addition, it discusses the power transition theory in the regional context and how the rising states can affect the process of the transition. The fourth chapter will include conclusion and summary of the research and the expectations for the future scenarios.

\section{Chapter Two}

\subsection{The Global Pattern of Interactions between Russia and the United States and Russia and the West}

The aim of the Russian foreign policy is to achieve its hegemony on the international system. This can be shown during the Cold War and how Russia challenged the United States in order to be a great power. Moreover, the Russian attempts after the collapse of the Soviet Union to revive the Soviet power again. In the 2000s, the Russian role in the international environment was marginalized because of the domination of the US. This chapter argues that Russia did not intervene in the Middle East before the Arab Spring because of its preoccupation with wars in western Europe in order to regain the Soviet doctrine in the region. This chapter will be divided into three sections. The first section discusses the Russian and American relations in the 2000s and the relations between Russia and the west. In addition, it discusses the effect of the Russian Wars on its relation with the west and the United States which can be shown through the war on Georgia and the second Chechen war. The second section discusses the economic status of Russia in the 2000s and the effect of the economic crisis on Russia. In addition, it discusses the Russia-Belarus energy dispute and Russia-Ukraine gas dispute and how it affected the relationship between Russia and the US. It discusses the effect of the economic crisis on the Russian economy and on the America-Russian relations. The third section discusses the Russian foreign policy in the 2000s in the context of power transition theory. 


\subsection{Overview of the Russian Foreign Policy in the 2000s}

The Middle East played an important role in Russian foreign policy since the second world war. After the collapse of the Soviet Union, the importance of the Middle East declined as a priority for the Russian foreign policy because of the political and economic instability of Russia whether nationally or internationally. When Vladimir Putin came into power in 2000, his main aim was to return Russia as a great power on the international sphere "The Russian Federation has acted in several scenarios and, since 2000, with Vladimir Putin, its main objective has been to consolidate the status of the Russian Federation as a great power, in order to return to the glorious Soviet era. Maximizing power and the pursuit of internal security are essential because there is an international system in permanent anarchy" [22]. In order to achieve Putin's foreign policy, he emphasized the importance of achieving national development to guarantee achieving long term foreign policy "foreign policy in the post-Soviet space is ultimately an extension of domestic policy, with both fundamentally directed at maintaining political stability" [23].

The main goal for achieving the Russian foreign policy includes two aspects which represented in increasing its influence, keep its prestige in the international sphere and achieving its economic growth. In order to achieve the Russian prestige in the international environment, Russia tried to keep good relations with the United States and the western powers as a way to recognize the role of Russia in the international sphere especially after the collapse of the Soviet Union "Russia's leaders seek recognition by major global actors-e.g., the United States, the EU, China, Japan, and India-that Russia is one of the major centers of power in an increasingly complex international environment. Russian decision makers do not want to relive the 1990s, when Russia, in its economic and political weakness, seemed to be a dependent of Western powers, one that followed their lead" [24].

To be taken into consideration; the economic growth of Russia plays an important role in its foreign policy in order to achieve its influence in the international system. The role of energy resources has directly affected the economic growth of Russia and its existence and influence as a hegemonic power; as it was the main provider for gas to Europe. This can be shown in August 2006 when Russia paid it debts to Paris Club despite the sanctions that were imposed on Russia. Russia took this step to reduce the obligations that are imposed by the west. As a result, in 2008 Russia restructured its fund into "A Reserve Fund designed to bolster the federal budget as oil prices drop and a National Prosperity Fund for investments in public works, education, health care, and agriculture" [24].

\subsection{The Russian-American Relations on 2000s}

Since Putin came to power, he was against American domination in order to achieve the supremacy of Russian at the international level. The Russian-United 
States relations have witnessed a change based on their interests. At the beginning of the rule of Putin, there was a hope for achieving cooperation between Russia and the United States. This can be shown post-September 11th. Putin declared his condolences to George W. Bush and his sympathy to the American people. In addition, Putin supported any action would be taken by the US. This cooperation took the form of military cooperation or alliance. Putin provided a plan consists of five elements to Support the war on terror by the US:

"He pledged that his Russian government would share intelligence with their American counterparts, open Russian airspace for flights providing humanitarian assistance, cooperate with Russia's Central Asian allies to provide similar kinds of airspace access to American flights, participate in international search and rescue efforts, and increase direct assistance-humanitarian as well as military assistance-to the Northern Alliance and the Rabbani government in Afghanistan" [25].

The Russian support to the presence of the American military in central Asia was to ensure the security of the Russian borders from the terrorist groups in Afghanistan. Moreover, it supported the sanctions that were imposed by the United Nations on the Taliban and it called for imposing sanctions on Pakistan as well because of its support to the Taliban. Russia did not want to lose its influence as the main producer for gas in central Asia "together, Russia, Iran, and the central Asian states hold more than half of the world gas reserves. Gas is not as mobile as oil and is destined for regional rather than the world market. Regarding a major role in central Asian gas production and export is a key issue for Russia's energy industry" [26]. Furthermore, Russia wanted to increase its investments besides energy investments. Thus, it supports the idea of reviving the trade between Russia and central Asia as it was before the collapse of the Soviet Union.

The shift in the relation between Putin and the US can be shown through the invasion of Iraq in 2003 by the US. However, there were some elements that led to worsen the relation between Russia and the US. In 2002, Russia declared its cooperation with Iran in the nuclear sector. This cooperation extended to include Iraq although it was refused by the American Ambassador Alexander Vershbow. In addition, signing the economic and trade deal between Russia and Iraq threatened the interest of the US in Iraq “with Russia and Iraq signing a \$40 billion economic and trade deal. As part of this deal, Iraq would expedite repayment on its multi-billion-dollar debt to Russia. This move was seen as a direct challenge to America's increasingly bellicose rhetoric toward Iraq" [27].

After the war, Putin decided to take the side of the European power and he joined an alliance with France and Germany against the invasion of Iraq. The three states agreed on the negative impacts of the unipolarity of the international system which represented in the domination of the US. This was directly declared by Putin during an interview in the French television:

"The main thing is that France and Russia have common approaches to con- 
structing the future edifice of international security. As we believe here in Russia, and as the French President Chirac believes, the future edifice of world security must be based on a multipolar world. This is the main thing that unites us. I am absolutely confident that the world will be predictable and stable only if it is multipolar" [27].

Although the oppositions of the three states, US invaded Iraq which was described by Putin as "unjustifiable and unnecessary war". Moreover, Putin described this war as a violation to the international law and the international security "If we allow international law to be replaced by might of the fist, according to which the stronger side is always right, may do as it likes and is unlimited in its choice of means to accomplish its goal, then a key principle of international law, that of the sanctity of sovereignty of all states, comes into question" [27].

The invasion of Iraq and the opposition of Russia to the US was an indicator for a proxy war. This proxy war can be shown in the Caucasus region whether in the Southern Caucasus which includes the newly independent states such as Georgia, Armenia, and Azerbaijan or the Northern Caucasus which include Chechnya "In the post-Soviet period, it has become one of the most volatile and potentially unstable regions in world politics. Fragile state structures, a series of unresolved or 'frozen' secessionist conflicts, and widespread poverty generate popular dissatisfaction and political instability" [28]. During this time, the importance of this region was more than the Middle East as a way to control the reserves of the oil and gas and due to its strategic location for confronting terrorism. Moreover, this region was used as a way for illegal trade and it witnessed Islamic radicalism "the Caucasus covers an important 'fault line' between Christian and Islamic civilization" [28]. Therefore, the importance of this region was equivalent to the importance of the Middle East nowadays as it was a place for coronation between the American and Russian interest which was called "new great game".

Although the Cold War has ended in 1991, the proxy war between the US and Russia did not end. The confrontations could be reduced but it did not end. The Russian Georgian war in 2008 is a great evidence to the statement above, as the US supported the Georgian regime of Saakashvili which was against the interests of Russia. The war started as a result of the declaration of Saakashvili to the inclusion of South Ossetia as part of Georgia. Georgia started the war by launching an attack over South Ossetia. Thus, Russia responded with counterattack via sea, air, and land to support the Russian peacekeeping forces in order to protect the Russian citizens and provide humanitarian aid [29].

Regarding the stance of the United States, Bush supported the Georgian side and he emphasized the importance of respecting the sovereignty of Georgia "Georgia is a sovereign nation, and its territorial integrity must be respected. We have urged an immediate halt to the violence and a stand-down by all troops. We call for the end of the Russian bombings" [29]. The United States response towards Russia in Georgia represented in returning the Georgian troops from 
Iraq to Georgia which made Putin accused the U.S. with its support to Georgia although Russia took these actions for protecting the Russian citizens and to maintain peace. United States asked Russia to withdraw from Georgia in order to save its relations with the U.S. and Europe. As what was declared by Bush administration officials that the U.S. aimed to maintain the cooperation between the U.S. and Russia against terrorism but the Russian-Georgian war will affect their relations [29].

The American support to Georgia over Russia can be explained as a way to control the gas and oil pipelines which serve the Israeli market for arms sales "Georgia, which the US valued primarily for reasons of control over gas and oil pipelines to Azerbaijan and Central Asia, and which Israel supported as a market for arms sales and in hope of obtaining the use of air bases from which to attack Iran, has been shorn of its small autonomous enclaves" [30]. Therefore, Russia was against the US support to Georgia as it threats its energy resources to the west. Russia showed to the world that its attacks were to protect its boards from any threats. In addition, to show to the world that its attacks did not lead to genocides as what the US did in Iraq in order to control oil.

On the other hand, the continuation of the hidden war between Russia and the US can be shown in the second Chechen war. The Chechen war started since 1999 when the Chechen president declared Chechen as an independent state after the collapse of the Soviet Union. Russia imposed the war on Chechen in order to avoid the separation of Chechen from Russia and to confront terrorism in Chechen which threats the Russian boards. In addition, it threats the Russian economy and democracy "It provides cover for the successors to the K.G.B. who are emboldened to harass Russian citizens. Most important, by soaking up Russia's scarce resources, the war weakens the response to the nation's socioeconomic crisis, which is a much graver threat to long-term security than anything that has happened in or around Chechnya in the past few years" [31].

The United States as a dominant power did not support Russia in the Chechnyan war as this war will increase the Russian influence in northern Caucus which threats the American geopolitics and its energy interests in the region. Hence, the Russian withdrawal or defeat in Chechen will serve the interests of the US which made the US supports the rebels in Chechen. The role of the US in the Chechnya war was different from Russia after the attacks of 9/11. Although Russia supported the US in the war against terror, the United States did not support Russia in its war against terrorism as the American support will serve the Russian interests [32]. The stance of US in Chechnya was different before and after the invasion of Iraq in 2003. The role of the US in this war revealed its covered foreign policy. It was described as:

"The hypocrisy of U.S. foreign policy" because in this war Russia imitated the American intervention in other states which made American keep silent on the Russian actions. This can be shown through what Bush declared before 9/11 and the American intervention in Iraq as he stated "we could cut off IMF aid and 
export/import loans to Russia until they heard the message loud and clear, and we should do that. It is going to be a very interesting issue to see how Russia merges... This guy, Putin, who is now the temporary president, has come to power as a result of Chechnya" [32].

However, the speech of Bush has changed after 9/11. After Bush's war on terror and his intervention in Iraq, his action changed. This can be shown through what Bush stated "our position in Chechnya is [that] we hope this can get solved peacefully, that this is an issue within Russia and that I can to encourage him for there to be peaceful resolution with the Chechen issue, the larger issue" [32]. The United States kept silent towards the Russian actions in Chechnya as the Russian intervention was the same as US interventions under the name of the war on terror. Therefore, US was afraid that any critiques to the Russian action or its violation to human rights in Chechen would be referred to the American actions "Russia's use of fuel-air explosives-bombs that cause similar effects to those of nuclear weapons-to destroy Grozny received only muted criticism because the United States had used the same explosives during its military campaign in the 1991 Persian Gulf War" [33]. Thus, US did not take direct action towards Russia. As if the United States had chosen to take a stronger stance on Chechnya, it would have called attention to its own past behavior [33].

\subsection{The Russian Relations with the European Union in the 2000s}

The Russian relation with Europe was different from its relation with the United States as both sides were trying to cooperate in order to face the external challenges. The collapse of the Soviet Union led to change in the geopolitical sphere as there were newly emerging states that were trying to achieve and protect its interests. This can be shown through the competition between Russia and Europe as each side was trying to increase its influence and expand its cooperation with these states:

“The EU's increasing geopolitical weight has taken concrete form through the development of its enlargement strategy and the launch of the Common Foreign and Security Policy (CFSP), followed by the Common Security and Defense Policy (CSDP). The European Neighborhood Policy (ENP) and, most recently, the Eastern Partnership (EaP) have been envisaged in the case of Eastern Europe as alternatives to the enlargement strategy, albeit this equivalency has not been officially stated" [34].

The main aim of Europe is to achieve security through the integration of the neighboring states. Therefore, Europe found eastern Europe as suitable for the integration especially these states are newly independent after the collapse of the Soviet Union which led to the competition between Russia and Europe on these states.

The European policies of integration of the newly independent states can be shown in 2004 during the big enlargement of Europe and before the integration of Romania and Bulgaria to the European Union "The EaP (2009) came about as 
a result of Russia's August 2008 invasion of Georgia (most prominently), the gas disputes between Gazprom and Kiev (2006, 2009), the growing interest in energy supplies, and the persistence of the protracted conflicts in Transnistria, South Ossetia, Abkhazia, and Nagorno-Karabakh" [34]. The relations between Russia and the neighboring states represented in three phases. The first phase was in the late 1990s and early 2000s and it witnessed a high level of cooperation between Russia and the neighboring states as Putin worked on increasing the Russian influence to ensure the continuation of the economic and political relations between Russia and the states that were in the Soviet Union [34].

Regarding the second phase which was in the mid-2000s. This phase has witnessed the increasing political role of Russia towards its neighboring states as a result of the "color revelations". In addition, it witnessed the increasing competition on the political and economic levels between Russia and the US and Russian and the European Union. This can be shown through the Georgian war and the stance the European Union took against Russia [34]. The third stage was during the last 2000s and is characterized by a long-term strategy through strengthening the Russian economy, military and its political relations with the regional states and the European states "This phase saw the development of a new cooperation and integration philosophy that was intended to boost rapprochement using more pragmatic mechanisms of mutual interest, especially in opening new markets and business opportunities" [34]. This shows how Russia was building its economy and military during the 2000s which made it qualified to intervene in the Middle East during the Arab spring. The Rethinking policy of Russia towards the neighboring states can be described as nostalgia to the Soviet era 1990s. In addition, Russia was trying to integrate itself in the international environment as it perceived the actions of the EU and the US as an attempt to exclude the Russian interests in the international environment.

The reaction of the European Union towards Russia in the Georgian war divided the EU states. Some of them supported Russia and others condemned it in order to contain the Russian integration in the region. There are states such as France and Germany which were neutral and perceived the position of Europe as supposed to be an honest broker. On the other hand, there are states which were against Russia such as Poland, Slovak, Britain, and Sweden which can be shown through what the Swedish prime minister stated regarding the Russian military "the gravest breach of the commitments of the Council of Europe" [35]. The geopolitical factor represents an important factor for European interests in the region as the EU aimed to establish an international energy market through the area of the black sea. Thus, the EU aimed to achieve stability in the region through portraying itself as a mediator. This can be shown through the peace agreement that was held by France as a mediator in the six-point agreement "In this six-point agreement it is mentioned that an 'international mechanism' should replace Russian peacekeeping forces in South Ossetia and Abkhazia” [36]. In addition, the EU appointed a minimum of 200 monitors for the implementation of 
the plan. The EU has succeeded to achieve stability, however, regarding the aspect that is related to cooperation among parties and the security it failed because of the division inside the EU regarding the war.

On the other hand, the reaction of the EU from Russia in the Chechnya war was different from Georgia as it took tougher actions because of the human rights violations that were adopted by Russia. The EU policies towards Russia represented in condemning the Russian human rights violations "In April 2000 it sponsored a resolution to the UN Commission on Human Rights calling for an independent national commission of inquiry on Chechnya to be set up" [37]. The EU break its partnership with Russia and it imposed an economic pressure on Russia as a way to force Russia to respect the human rights which were declared by the French foreign minister. Furthermore, the Scandinavian and Baltic states-imposed sanctions against Russia [38]. The EU used the accusations to Russia for violating human rights as a tool to gain leverage over Russia in the region especially the post-Soviet era due to the clash between the Orthodox geopolitics that was promoted by FSU and liberal democracy that was promoted by the EU and the US [39].

\subsection{The Russian Economy in the 2000s}

The collapse of the Soviet Union did not only affect Russia economically. Russia was ranking the second place economically after the US during the Cold War. After the collapse of the Soviet, it was not included in the ten powerful economies in the world. However, the Russian economy recovered during Putin's rule "Since the advent of Putin to power, growth rates have averaged 7 percent, it is higher than the world average of 5 percent and two to three times higher than those in the US and Europe. In 2005, the Russian GDP amounted to $\$ 763$ billion. However, in purchasing power parity terms this figure was estimated at $\$ 1.56$ trillion in 2005 and \$1.67 trillion in 2006" [40] Energy resources have played an important role in the economy of Russia "It is number one in natural gas reserves amounting to 32 percent of the world's total. Its share of world oil reserves is estimated at $17-18$ percent, of world palladium at 50 percent, of world nickel at 40 percent, of world iron ores at 30 percent and of world uranium at more than 10 percent" [40].

Putin's economic policies aimed to achieve the economic growth on the international and domestic levels especially after 1998 currency crisis "Economic growth and high world fuel prices helped the government to collect more tax revenues, so the government budget moved from a deficit to surplus, and government spending as a proportion of GDP increased since 1999" [41]. In addition, the increasing prices of the oil and gas in the international markets led to achieving high surplus in the foreign trade "which increased from less than $\$ 15$ billion right after the 1998 currency crisis to nearly $\$ 500$ billion at the beginning of the 2008" [41]. Furthermore, the economic policies of Putin led to increase the national income "Russia had 53 billionaires in 2007 according to Forbes, a 
statistic that propelled the country to the second/third place in the world after the US and Germany. In 2008, Forbes reported 87 billionaires in Russia, with a total wealth of roughly half a trillion dollars, making Russia only second to the US" [41]. The successful economic policies of Putin led to achieve stability which made citizens willing to elect Putin for another term.

\subsection{Russia-Belarus Energy Dispute}

The importance of gas to the Russian economy can be shown through Russia-Belarus energy dispute in 2004 and 2007. The dispute began when Putin declared in one of his statements that the main reasons for the flourish of Belarus' economy are its dependence on the Russian partnership not as what Lukashenka said based on Belarus itself. As a result, Lukashenka abandoned the ruble as a single currency with Russia which led to a price dispute between Russia and Belarus which made Gazprom stop the gas supply to Belarus [42]. The Russian control over gas presented a threat to the US and the EU especially on the EU as Russia represents the greatest gas reserves in the world. Hence, this will lead to increase the EU dependence on Russia which will give Russia a chance to control the prices of gas as there are no global prices for oil. In addition, it will give Russia more integration in the region [43].

\subsection{The Gas Dispute between Russia and Ukraine}

The reasons for gas dispute between Russia and Ukraine are similar to Belarus and Russia gas dispute due to disagreements on the price of Russian gas to Ukraine and the tariffs of the transit to Europe "In late 2007, import prices for 2008 gas supplies to Ukraine were set at $\$ 179.50 / \mathrm{mcm}$, up from $\$ 130 / \mathrm{mcm}$ in 2007; all imports were to be sold by RUE to Ukrgaz-Energy at the Ukrainian border. Transit tariffs were set at $\$ 1.70$ per thousand cubic meters per hundred kilometers, up from $\$ 1.60 / \mathrm{mcm} / 00 \mathrm{~km}$ the previous year" [44]. As a result, Russia stopped its gas exports to Ukraine and the dispute escalated in 2009. The Russian dispute against Ukraine increased the fears of the EU towards Russia as it undermines the political and economic influence of the EU especially the energy supply. The response of the EU towards the dispute was not united. For instance, central Europe condemned the Russian violence in Ukraine such as Poland, Estonia, and Lithuania. On the other hand, the southern Europe response was not effective as central Europe. It preferred returning the status quo due to its fear from central Europe "Initial responses from countries further south were much more subdued. They ranged from lukewarm condemnations of Russia's actions by Bulgaria to a markedly distanced attitude toward the EuroMaidan protests in Romania, and from quiet pragmatism in Slovakia to vocal pro-Russian voices in the Czech Republic and Hungary" [45].

\subsection{The Effect of the Economic Crisis in 2008 on Russia}

The economic growth that was achieved by Putin did not last because of the 
economic crisis in 2008. The economic crisis affected the Russian companies such as Gazprom which plays an important role in the Russian economy "Even though it was not one of the companies that were hardest hit, nonetheless, within just five months, Gazprom's stock, which reached a high of 15.45 rubles on May 19, 2008, fell by more than 80 percent to a low of 2.9 rubles on October 24 , 2008. As for its capitalized value-the sum total of all Gazprom stock-that fell $\$ 250$ billion, from $\$ 330$ billion in late 2007 to $\$ 83$ billion in October a year later" [46]. The economic crisis led to increase the rates of unemployment, decreasing wages and industrial productions. Moreover, decreasing the value of the ruble in foreign exchange rates "Both the fall in the ruble's value and the fall in stock values were inevitable given the predominance of energy stocks in the Russian market and the large foreign borrowings of many of the major Russian firms" [47].

The effect of the economic crisis on the American-Russian relations can be shown through the American policies which aimed to cooperate with its European allies in order to undermine Russia from regaining its economic status in the international market "Working together, the nations of Europe could formulate and implement effective and realistic free-market energy policies. The U.S. should also work with them to apply anti-monopoly legislation to Russian government-owned companies if Moscow continues to deny upstream access to Western companies" [48]. As the energy resources are the cornerstone for Russia's economy, the US tried to gain the energy influence instead of Russia "The weakening of Russia's energy, military, and financial clout has made it more difficult for Moscow to openly flout international norms or aggressively challenge U.S. hegemony" [49]. Although there was a challenge between the American and the Russian interests, each of them was trying to recover from the economic crisis. Thus, in 2009 there was a rapprochement between Russia and the US in trade during the crisis as it was perceived from the Russian perspective as "The economic cooperation is the basis for the reset" [49]. In addition, both of them signed an arms control in 2010 which replaced the first Strategic Arms Reduction Treaty. This negotiation was important for the Russian side especially after the lack of their military capabilities. Furthermore, the Russian economic recovery represented in the devaluation of the Russian currency and the tax reforms were included "like other resource-dependent countries, Russia's normal measures of real effective exchange rates have basically returned to their pre-crisis levels. And fluctuations around the equilibrium exchange rate-whatever that might be-are to be accepted in a hydrocarbon-dependent country with either a managed float or a pegged exchange rate" [50].

\subsection{The International Environment in the Context of Power Transition Theory}

Power transition theory can be shown in the 2000s through the process of transition which was stable during the beginning of 2000s. This can be shown through Russian satisfaction with the American policies and its close relation- 
ship with the US against terrorism. Russia was satisfied with the American policies in order to achieve its interests which represented in achieving the Russian security and protecting its border as Russia was exhausted after the Cold War. The beginning of the transition process started with the Russian dissatisfaction of US actions in Georgian and Chechnyan war. In addition, the EU actions that were against the Russian interests in Belarus and Ukraine gas disputes which represented in a race between them for gaining more influence in the region. The main aim for Russia was focused in the Eastern Europe instead the Middle East due to its fear from the expansion of the NATO and the missile defense system of the US. Although the US emphasized that its main aim of the missile system was not directed against Russia, Russia did not believe the American claims and accused it for undermining the missiles and the nuclear capabilities of Russia [51].

The factor that encourages Russia to challenge the US represented in the Russian accumulation of resources which represented in the flourish of the Russian economy due to Putin's economic policies. Despite the economic crisis which affected the Russian economy, Russia succeeded to recover faster than most of the European states. The recovery of Russian economic in tandem with the Arab uprising. It was an opportunity for Russia to continue the transition process and challenge the US. Although Russia had a strong economy which could make it qualified to intervene in the Middle East during the 2000s, its main focus was on the Eastern Europe states as it wanted to regain its influence again after the collapse of the Soviet Union. Thus, with the rising of the Arab uprising and the shift of the American interests more in the middle east, Russia shifted its focus towards the Middle East and the Arab spring was the chance to revive its Soviet doctrine.

To conclude, the 2000s represented the era of the Russian attempts in order to revive the Soviet Union. Thus, Russia directed its focus towards Eastern Europe as it included the states that were part of the Soviet Union which illustrate why did not Russia intervene in the Middle East in 2000s. The 2000s is considered a stage for preparing Russia to challenge the US in the Arab Spring and to achieve its influence.

\section{Chapter Three}

\subsection{The Regional Presence of Russia in the Middle East during the Arab Spring}

The Arab spring represented an opportunity for Russia to achieve the transition through challenging the US hegemony in the Middle East. Thus, Russia tried to regain its ties with different states in the Middle East such as Egypt, Libya, and Iraq. In addition, improve its relations with its traditional allies such as Syria and Iran even it tried to gain ties with sub regions such as the gulf which has strong ties with the US. This chapter argues that Russia intervened in the Middle East during the Arab uprising in order to challenge the American presence in the re- 
gion which threatens its influence. This chapter is divided into three sections. The first section includes an overview of the Russian foreign policy towards the Middle East during the Arab Spring and the beginning of challenging US policies in the cases of Egypt, Tunisia, Yemen and Bahrain. The second section discusses how Russia challenged the US in the cases of Libya and Syria which were indicators for the transition. The third section discusses the Chinese-Russian relations and its effect on the US hegemony.

\subsection{Overview of the Russian Foreign Policy in the Middle East during the Arab Spring}

At the beginning of the Arab Uprising, Russia perceived it as an attempt by the western power to destabilize the international system in order to enforce its values and its domination. Thus, Russia intervened in order to not being marginalized "Considering the Arab Spring as, at least partially, a U.S. and EU plot, the Russian government felt it had no choice but to become more deeply involved in the situation on the ground in order to balance the destabilization of the political situation in the Middle East by Western powers and to prevent repercussions in Eurasia" [52]. The Russian intervention in the Middle East focused on three aspects which are; security, economic and political aspects. Regarding the security aspect, Russia aimed to reduce the security threats which undermine its stability especially after the Arab uprising which led to the instability of the international system. Hence, it can affect the Russian stability. The economic aspect represented in securing the Russian energy resources that increase the Russian influence in the international system. The political aspect includes the fears of Russia from being isolated due to the policies of the US and the EU [52].

Besides these aspects, there were some elements that encouraged Russia to intervene in the Middle East. The first element is protecting the Russian red lines in the region. The Russian intervention in the Middle East has to define its red lines in the region as it did not support the regime changes. The second element which is related to the idea of reviving the Soviet doctrine through increasing the Russian influence in the region "The Kremlin does not directly oppose Washington, but rather exploits the region's pre-existing disappointment with the United States through practical moves, which contrast with Western behavior" [52]. Regarding the third element which refers to the economic efforts that Russia aims to achieve in the Middle East. Although this region shares a small parentage of the Russian investment, it has an important role in the Russian industries such as agriculture, military, and petrochemical industries "Israel and the UAE buy up to $16 \%$ of the precious stones and metals exported by Russia. The Middle East is the main destination for exports of Russian grain; by 2016, the largest buyers of Russian wheat, rye, and barley were Egypt, Israel, and Saudi Arabia, respectively" [52].

Furthermore, the Russian foreign policy in the Middle East during the Arab spring aimed to secure its energy resources whether for the supply or the de- 
mand. In order to achieve this strategy, Russia needs to increase its cooperation with the Middle East countries to achieve commercial and political influence of Russia in the region "Russia and MENA sit on $60 \%$ and $63 \%$ of the world's proven oil and gas reserves, respectively, and produce half of the world's oil and nearly $40 \%$ of its gas. Any cooperation between these two giant players will, therefore, have significant implications for global oil and gas markets" [53]. Moreover, Russia found a chance in the Arab uprising for regaining its status as a great power. In order to regain this status, Russia portrayed itself as a mediator in the conflicts which can be shown through its role in Syria and Libya "The fall back approach to dealing with conflict, harking back to their strategy throughout the Cold War, is for Russia to use its connections to both sides of the conflict to mediate" [54]. The role of Russia as a mediator in Libya would allow Russia to return as a great power in the Middle East "A Russian-mediated end to the war [in Libya] would have enshrined Moscow's return to the Middle East as a major player and proven to the West that the Kremlin was indispensable in settling regional conflicts" [54].

\subsection{The Arab Uprising in Tunisia, Egypt, Yemen and Bahrain}

Although the Arab uprising threatened the Russian influence as it was afraid of increasing the influence of western power especially the United States. Russia perceived the Uprising as the color revolutions which were encouraged by the US in the Eastern Europe. Russia considered the Arab Spring as a chance to increase its influence and regain the Soviet legacy [2]. Although at the beginning Russia was against the Arab spring, its stance changed later as it perceived the Arab Spring as a tool to change the balance of power for itself "Russia, thanks to its rising political profile as a world power in recent years, emerged as one of the major players that need to be taken into account in the design of the new Middle East. In this process, Russia has found an opportunity to rebuild her lost leverage in the Middle East and this has further strengthened her hand as a regional and world power" [55]. The Russian responses to the cases of the Arab uprising were varied based on its relation with these states whether having strong ties and cooperation between them or not. In addition, the Russian interest in these states. The Russian doctrine towards the Arab Spring can be divided into three doctrines. The first doctrine represented in waiting strategy and not taking any rapid actions which explain why the Russian stance towards the uprising in Tunisia and Egypt was passive. The second belief refers to classifying the uprising as an internal issue. The last doctrine refers to preventing any international interventions in order to avoid the escalations of the uprising. Hence, the instability in the region [55].

The Russian stance towards the uprising in Tunisia, Egypt, Yemen, and Bahrain was passive. Its role was described as a spectator due to the lack of the economic ties with these states and the lack of connection between their leaders. Regarding the cases of Egypt and Tunisia, the Russian role was muted as Russia 
did not have strong tries with Tunisia or Egypt as they have strong relations with the US. Russia perceived the uprising in Tunisia as a lesson for the other governments. On the other hand, in the case of Egypt, Russia emphasized the importance of the peaceful transition "Russia and Egypt have no political contacts of any significance. Neither Moscow nor Cairo show any real desire to expand them, especially because there is no pressing economic reason to do so (Egypt's trade with Russia represented just $0.3-0.4$ percent of its total foreign trade in 2008)" [2].

The stance of Russia was not different from the west in the case of Bahrain. Russia perceived the uprising in Bahrain as an internal issue which has to be solved through dialogue. Although the uprising was by the Shia sects which are supported by Iran (which represented an important ally to Russia) according to the Saudi perspective, Russia did not support the uprising and it did not even object for solving the issue through violence. The Russian relations were normalized with Bahrain as there is nothing happened in order to maintain stability in the Gulf region which represents an important region for the Russian oil. This can be shown through the visit of the Russian First Deputy Prime Minister Viktor Zubkov in January 2012 to Bahrain "In order to discuss the possibility of establishing direct air service between Moscow and Manama as well as economic and cultural cooperation as if nothing untoward had ever taken place in Bahrain" [56].

On the other hand, the case of Yemen was one of the cases that Russia did not want to be included in. It just called for peaceful solutions among the parties. The Russian unwillingness to intervene in Yemen was due to its fears from losses. In addition, it did not have strong ties with Yemen "The Kremlin perhaps took the view that it was risky to intervene in Yemen's affairs because the situation there was so complicated and the extremists had a lot of influence; as one Russian newspaper put it, "it would be easy to get involved in Yemen, but the consequences would be serious" [2]. The previous cases show how the Russian stance was not different from the west as Russia did not have interests in these states as the race between it and the west was equal.

\subsection{Russian Challenge to the United States in Libya and Syria}

The Russian intervention in Syria and Libya emphasizes the assumption of the power transition theory which refers to the dissatisfaction of the states about the dominant power that leads to challenge it. The same regarding the Russian intervention in Syria and Libya as a challenge for the US domination which represented a threat for the Russian interests. This shows how the policies that Russia adopted during the 2000s were to make it qualified to intervene for achieving the transition and the Arab spring was that opportunity:

"Although Russia has worked painstakingly to rebuild its influence and standing in the region since the mid-2000s, its efforts only began to pay off meaningfully in the wake of the Arab Spring. This is when Russia's resurgence in the region 
became clearly evident, culminating with the first major combat deployment of the Russian armed forces in 2015 in a war theatre located far beyond the post-Soviet neighborhood" [53].

The Russian intervention in Libya was due to its economic interests in Libya which traced back to 2008 "In April 2008, Russia canceled Tripoli's USD 4.5 billion debt, which had originated during the Soviet era. As a result, Russian companies received Lucrative contracts" [57]. These contracts were estimated to be USD 10 billion. The Russian interests in Libya represented in the oil sector and as an importer for the Russian weapons. Moreover, the Libyan crisis questioned the principles for humanitarian intervention and the role of UN and NATO in managing the crisis which services the Russian interests as a great power. The uprisings in Libya were different from Tunisia and Egypt. The uprisings in Libya did not depend on the peaceful means and it included foreign intervention. Russia was against any intervention from the external forces as it would lead to the rise of Islamists which threat the Russian stability "Prime Minister Vladimir Putin warned that 'external interference' could lead to the rise of Islamists, and that their rise in North Africa could negatively affect other regions, including Russia's North Caucasus" [56]. Russia was afraid that the intervention by the external powers will lead to a political change in Russia.

As a result of the violence in Libya, the 1973 resolution was applied by the UN security council in order to protect the civilians. Russia did not vote for the resolution. As Russia perceived the resolution as a way for intervening in the internal affairs which represents a disrespect for the Libyan sovereignty. Libya is considered a unique case in the Arab uprisings as Libya represents the starting point of the American and Russian challenge in the Middle East. Libya is considered an important ally for Russia, US and the European states in the energy resources especially the oil. On one hand, the importance of Libya to the European states represented in controlling the energy resources and achieving economic integration in order to achieve stability for the west. The European states had more interests in the oil and gas in Libya than the US as "The European allies were getting gas and oil from Libya through enormous contracts. How the Libyan crisis had affected European countries' economic interests as evidenced by the increase of oil prices to their highest levels since the global financial crisis of 2008 due to Gaddafi's plan to end Libya's National Oil Corporation's (NOP) contracts with Western oil groups including oil giant BP" [58]. Moreover, Libya represented an important region for the security of the European states as Libya is close to Europe geographically which allows the refugees to flow to Europe through it.

On the other hand, the American interests in Libya represented in two aspects. The first aspect refers to supporting the uprisings in other Arab states as the US aimed to show them how it will be intolerant for any oppression against the uprising. The second aspect represented in the external pressure imposed on the US such as the Arab League, France, and Britain. The United States did not 
want to be isolated. Furthermore, the US wanted to support its European allies as in case of losing control on the Libyan situation will affect the security and stability of its allies. Hence, it would affect the security of US “There was a concern that if the situation went out of control in Libya, anxieties would spread across borders to the east and west of Egypt, thereby lots of refugees would go to Europe, which would become a tremendous threat to the allies" [58].

As a result of the American challenge to the Russian interests in Libya, Russia decided to revenge from the US in Syria. Syria represents an important ally to Russia more than Libya. Thus, the Russian reactions towards the US policies in Syria were more assertive. Russia portrayed itself as a protector for Syria which made it non-hesitant to go in conflict with the US and the European states. It opposed the regime change in Syria as it represents a threat for the Russian interests in Syria due to in strong ties with the regime which was stated by $\mathrm{Mu}$ socco times "Russian investment in Syria totaled USD 19.4 Billion in 2009" [57]. In addition, Syria plays an important role in the Russian energy and arms companies as Syria represents the third important arms market for Russia. Regarding the Syrian importance for Russia in energy resources, it can be shown through the gas facilities that were built by Stroitansgaz near Homs and Tatneft which benefited the oil funding in Syria.

Furthermore, the importance of Syria to Russia represented in the military aspect as Russia has a naval base in Tartus. This base will help Russia to enforce its influence in the region whether militarily or fighting against terrorism in the region. Moreover, Syria is important for the geopolitical interests of Russia. Syria provided political support for Russia in the war in Georgia and Chechnya. Russia uses Syria as a tool to counter the American influence in the region. Thus, the collapse of the Assad regime will lead to great losses for Russia economically and geopolitically [57]. Russia disagreed with any foreign intervention in Syria as it has learned from the Libyan case "Based solely on its diverse interest in Syria, Moscow would use its veto power in the UN security council in order to prevent military intervention or a weapons embargo against the Assad regime" [57].

On the other hand, the US insists to intervene in Syria in order to limit the Russian influence in the region. The geopolitical interests of Russia in Syria started to challenge the American influence in Syria. The close Russian relations with different actors inside Syria such as Iran, Turkey, and Israel threatened the American influence in Syria "Russia's involvement in Syria has given its relations with neighboring countries a new momentum. Despite divergent interests, Iran, Turkey, and Israel cooperate with Russia and acknowledge its leadership in Syria" [59]. Russia had strong ties with Turkey as it represents an important exporter to the Russian oil and it is a partner with Russia in Turksteam gas pipeline which service the commercial and geopolitical interest of Russia. The Russian relation with Iran is based on the adversary that can be traced back to the historical hostility between them. Despite the hostility between Russia and Iran due to the close relation of Russia with Israel in Syria, their partnership is based 
on specific common interests as both of them supports the Assad's regime "Such differences mean that the Russian-Iranian relationship should be seen as a tactical alliance based on specific issues where interests converge, rather than a longer-term strategic partnership reflecting fundamental similarities in the two countries' world views" [59].

Regarding the relation between Russia and Israel, it represents one of the great threats to the US as Israel represents an important ally to the US. The Russian Israeli relation is not identical as each side perceives itself as a legitimate actor in Syria. However, Russia tried to gain a good relationship with Israel as Russia was afraid that Israel could prevent the Russia from achieving its influence in the Middle East. On the other hand, the main aim of Israel is to control the Golan Heights in Syria and the Russian presence in Syria could hinder the Israeli control over it. Thus, each side tried to gain a good relationship with the other side. Russia was trying to develop its ties with the major actors in Syria in order to reinforce its position to avoid any division among them "Having good relations with nearly all of the Middle East's feuding actors-a feat the United States cannot claim-Russia positions itself as the indispensable middleman" [60].

Increasing the Russian influence in Syria was supported by China, which was against the UN security council resolution which imposed sanctions on Assad's regime which can be shown through what China-watcher Yun Sun stated, "While Beijing saw little to lose, it saw much to gain by vetoing the Syria resolution. China's veto saved Moscow from international isolation... a favor that Russia now has to return" [57]. The important role that China played in Syria and its economic effort represents indicators for the transition. Russia and China had enough economic resources which encouraged them to challenge the US as a hegemonic power.

\subsection{The Russian-Chinese Relations in the Context of Power Transition Theory}

With the recent rise of China and its increasing role in the international system, the process of transition might end as a bipolar or multipolar. The rise of Russia and China changed the balance of power and challenged the US domination on the international system:

"There is increasing convergence between Russia and China on several global issues. Moscow and Beijing openly coordinate positions on these issues, particularly in the UN Security Council. They are also engaged in multilateral fora such as RIC, SCO, and BRICS, and see such an engagement as one way of strengthening a multipolar world in which they are key players as well as a platform to present an alternative viewpoint to the Western-dominated global discourse" [61].

The United States became no longer the hegemonic power in terms of economic, political or military aspects. The political relations between Russia and China characterized as being transitional which led to change the nature of 
threats for both of them. The economic relations between Russia and China are in harmony "Economic relations are portrayed as the 'new strategic basis' for Sino-Russian relations. China is Russia's biggest trading partner and the largest Asian investor in Russia. China sees Russia as a powerhouse of raw material and a growing market for its consumer goods" [61].

The close relationship between Russia and China led to the fear of the newly emerging states such as India which made it working on protecting its interests through different strategies such as increasing its relation with Russia in order to be balanced against China. Moreover, India developed its relationship with the US in order to balance any partnership between Russia and China. The rise of several powers at the same time in the international system can lead to two possible scenarios whether the cooperation among these states or increasing the conflict among them. This can be shown through the Russian-Chinese relations. On one hand, there is an economic and political partnership between Russia and China which keep their relation close. On the other hand, there is a lack in the military partnership between them as each side has fear from the other side regarding the unequal military power between them. However, the Russian fears from China represented in the unequal relations regarding the conventional forces "Russia knows that despite its superiority in terms of nuclear weapons, its conventional forces are no match to China's military. China, on the other hand, fears being encircled and isolated if Russia joins the West" [61].

Recently, Russia focused on improving its military activities which can be shown through the Chinese military white paper in 2015 that includes the Chinese military strategy. It shows the transformation of the Chinese defense mentality and the national security strategy of China. It emphasized that hegemony is not the objective "China will unswervingly follow the path of peaceful development, pursue an independent foreign policy of peace and a national defense policy that is defensive in nature, oppose hegemonism and power politics in all forms, and will never seek hegemony or expansion" [62].

Although China emphasized the stance for not being the hegemon power, its military actions show its intention for being a great power. This can be shown through the Chinese military deployment in Djibouti in order to protect its commercial and military interests "China also used its soft military naval presence overseas, specifically in the Middle East, to protect its expanding commercial interests and as a platform for military diplomacy. In May 2015, Chinese and Russian naval vessels held joint naval exercises in the Mediterranean, the first in European waters in the Black Sea and the Mediterranean and the farthest-ever from China's home waters" (Chaziza, 2018, p. 14). Furthermore, China tried to increase its influence economically in the Middle East. This can be shown through the belt and road indicative in 2013. It was launched as a result of the shift of US policies towards Asia due to the rising influence of Russia and China in the Middle East which undermine the US policies in the Middle East [63]. Losing Syria is one of the most important indicators of the transition as it shows 
the loss of the US influence in the region and the Russian gain in the Middle East. As a result, Trump declared lose to Syria and he withdraw from Syria. Trump Justified his withdrawal as the American intervention in Syria costed the US losses in the number of soldiers. Moreover, Trump denied the role of the Arabs and the Kurdish in fighting against the Islamic state instead he related it to the role of the US only [64].

The context of power transition theory on the regional level in the Middle East shows that the transition is still in the making. The transition shows that the unipolar system is no longer existing as there are rising powers which challenged the American hegemony in the region. This shows that Russia is not the only power that seeks to achieve its influence in the international system which means that the transition may end with being bipolar or multipolar. The recent military deployment of China shows that Russia will not be the only dominant power. In addition, the rise of BRICS which indicates that the international system may be classified as a multipolar system. Whether the international system becomes bipolar or multipolar Russia succeeded in challenging the US hegemony. After Trump came to power and with his aggressive policies that he took against some Arab States which made them dissatisfied about the US as a hegemon power. He put restrictions on travelers from five countries that the majority of them are Muslims. In addition, his decision to move the American embassy to Jerusalem "In addition, a perceived US retreat from global leadership creates more room for Russia to expand. Russia's growing influence in the region, therefore, reflects US weakness as much as its own strength" [59].

To conclude, Russia intervened in the Middle East after the Arab Spring as a result of increasing the involvement of the US in the region which undermines the Russian interests especially in Syria. Syria played an important role in the process of the power transition as it led to undermine the interests of the US in the region and changed the balance of power.

\section{Chapter Four: Conclusions}

The Russian-American relations have been always in conflicts. Even after the collapse of the Soviet Union, the hostilities between them can be reduced but it did not end. As each side tries to gain more power and influence in the international system. The main aim of the Russian foreign policy is to regain the Soviet doctrine. The issue of reviving the Soviet doctrine can be discussed in the context of the power transition theory whether on the global or regional level due to different factors such as economic, political and military that encourage for the transition. The power transition theory emphasizes about two main assumptions in order to achieve the transition. The first assumption refers to the degree of the satisfaction of the states on the hegemon power. The second assumption emphasizes the importance of the states for having resources in order to challenge the dominant power. When there is a dissatisfaction on the hegemon power and the states have enough resources, which make them qualified to challenge the he- 
gemon power, the states can be able to reach transition.

The same can be applied to the Russian-American relations since the 2000s which shows how the process of transition began. During the 2000s when President Putin came to power, his main focus was to return the Russian influence in the international system. The relation between Russia and the US at the beginning of the 2000s was close as Russia supported the US actions towards terrorism in order to secure its borders. The shift in their relation started after the invasion of Iraq by the US which presented as an indicator for challenging the US domination. As Russia perceived the invasion of Iraq as a disrespect for the Iraqi sovereignty and it believed that it would lead to the instability if the international system. Thus, Russia cooperated with the western power as it perceived the multipolar system will achieve stability.

The stance of the western power was divided regarding the issue of Georgian war. Regarding the stance of the US supported Georgia against Russia. As the US wanted to weaken the gas and oil pipelines of Russia in the action of the European Union, some states supported Russia and others were against it, however, they all have agreed on achieving stability in the region in order to establish an international energy market. On the other hand, the war in Chechnya was not supported by the US as the US perceived any support for Russia in the war will lead to increase the Russian influence in the region. The reaction of the EU towards Russia in Chechnya war was more aggressive than in the Georgian war as it accused Russia with committing a human rights violation. These two wars were an indicator of the Russian challenge to the US in the Middle East.

One of the most important indicators in the process of transition is the accumulation of resources. This can be shown through the Russian economic growth that was adopted by Putin on the domestic and international levels before the economic crisis. The energy resources represented an essential element in participating in the Russian economic growth. In addition, it threatened the American domination in the region as it gave Russia more influence. This can be shown through the gas dispute between Russia and Belarus and between Russia and Ukraine. The US was afraid of losing its European allies that have a close relationship with Russia in gas and oil cooperation. The economic crisis in 2008 affected the Russian economy and represented a chance for the US to weaken the Russian influence. Moreover, the economic crisis prevented Russia from intervening in the Middle East as the economy and the accumulation of resources represent important factors in the transition process.

Regarding the reaction of Russia towards the Arab uprisings, in the beginning, Russia was against the Arab. Russia perceived the Arab uprising as an attempt from the western powers to weaken the Russian influence. In addition, it threats the gas and oil reverses in the Middle East. Thus, stayed silent in the uprisings that were in Tunisia, Egypt, Yemen, and Bahrain. Russia was against the regime change as it would lead to instability in the region. Furthermore, these states do not have strong ties with Russia. The Russian reaction towards the uprisings Tu- 
nisia and Egypt represented in calling for a peaceful transition. In the case of Bahrain, it perceived the Uprisings as an internal matter. Regarding the case of Yemen, Russia never had a desire to intervene in Yemen as it would lead to massive losses to Russia.

On the other hand, the stance of Russia towards the uprisings in Libya and Syria was different due to their importance to Russia. Russia has strong ties with Libya, especially in the economic relation. As a result of the escalation of the situation in Libya, the security council declared 1973 declaration which was not approved by Russia as it threats the Russian interests in Libya and will lead to instability of the region. The case of Libya represents an important part in the process of the transition, as Russia lost a lot of its interests in Libya because of the US. Thus, Russia did not give the US a chance to repeat the scenario of the Russian failure in Libya in Syria especially Syria represents the most important ally to Russia in the Middle East. Syria has strong ties with Russia in different aspects military, economic, political and security aspects. Thus, the failure of the Russian influence in Syria means the failure of the Russian influence in the region. The Russian presence in Syria represents a massive threat to the US due to the Russian relations with the different actors in Russia such as Israel, Iran, and Turkey.

The process of transition still in the making especially with the rising of newly emerging states such as China, India and BRICS which changed the balance of power and challenged the domination of the US. However, there is no specific point that can be described as the transition, it is a gradual process which can take years. There are two expected scenarios of the Russian relation with newly emerging states, whether Russia cooperates with the other emerging states and the international system will be multipolar or Russia will return to the era of the Cold War and there will be a confrontation between it and China, which will end with the failure of one of them. Hence, one of them will rise as a dominant power. One of the most important indicators that show the current transition of power can be shown through tracking back to the US influence after the invasion of Iraq and how the US was the hegemon power that cannot be challenged. By looking nowadays to the influence of US in the Middle East, it is not the same as it was in 2000s or even at the beginning of the Arab Spring until Russia emerged as a key actor in the uprisings in Libya and Syria. As a result, US shifted its policies to the Eastern Asia as it founded its role in the Middle East became no longer effective. In addition, Russia worked on formulating allies with the states in the Middle East which can be shown through the case of Syria and the cooperation of Russia with different states such as the of case Israel and Iran. Russia also tried to gain the support of the Gulf states such as in the case of the uprising in Bahrain and the stance of Russia in supporting the king. As a result of the American Cold War mentality that US insisted to follow, Russia and China did not want to be excluded from the international system which made them to challenge the US policies in the Middle East. This can be shown through the po- 
litical, economic and military role that Russia and China played in the Middle East which led to change the balance of power. Hence, led to the power transition in the international system. Accordingly, affecting the power transition in the international system.

\section{Acknowledgements}

I would like to thank my supervisor professor Gamal for being helpful and for his great efforts throughout the year. Also, I would like to thank him for his permanent advises and instructions. I have learned a lot from them. Finally, I would like to thank my parents for their permanent support and for always being in my back during my stressful days. I am really grateful to them.

\section{Conflicts of Interest}

The author declares no conflicts of interest.

\section{References}

[1] Sladden, J., Wasser, B., Connable, B. and Grand-Clement, S. (2017) Russian Strategy in the Middle East. RAND Corporation, Santa Monica.

https://doi.org/10.7249/PE236

https://www.rand.org/content/dam/rand/pubs/perspectives/PE200/PE236/RAND_P E236.pdf

[2] Malashenko, A. (2013) Russia and the Arab Spring. https://carnegieendowment.org/files/russia_arab_spring2013.pdf

[3] Borshchevskaya, A. (January 24, 2013) Russia’s Many Interests in Syria. https://www.washingtoninstitute.org/policy-analysis/view/russias-many-interests-in -syria

[4] Dyner, A.M. (February 9, 2018) The Political and Military Consequences of Russia's Involvement in Syria.

https://www.ceeol.com/search/gray-literature-detail?id=853669

[5] Polyakova, A. (February 26, 2018) Putin's True Victory in Syria Isn't over ISIS. https://www.brookings.edu/opinions/putins-true-victory-in-syria-isnt-over-isis/

[6] Wakim, J. (2015) Russian Troops in Syria: Ensuring Access to the East Mediterranean. In: Mohseni, P., Ed., Disrupting the Chessboard: Perspectives on the Russian Intervention in Syria, Belfer Center for Science and International Affairs, Cambridge, 27-29.

https://www.belfercenter.org/sites/default/files/legacy/files/Russia\%20in\%20Syria\% 20-\%20final\%20web\%202.pdf

[7] Beccaro, A. and Maass, A.S. (2017) The Russian Web in the Mediterranean Region. https://www.ispionline.it/sites/default/files/pubblicazioni/analisi308_beccaro_maass 22.02.2017_0.pdf

[8] Zvyagelskaya, I. (2015) Russia's Strikes in Syria: New Risks or a Window of Opportunity? In: Mohseni, P., Ed., Disrupting the Chessboard: Perspectives on the Russian Intervention in Syria, Belfer Center for Science and International Affairs, Cambridge, 30-33.

https://www.belfercenter.org/sites/default/files/legacy/files/Russia\%20in\%20Syria\% 20-\%20final\%20web\%202.pdf

[9] Saradzhyan, S. (November 17, 2015) Russia’s Actions in Syria: Underlying Interests 
and Policy Objectives.

https://www.russiamatters.org/sites/default/files/media/files/Russian\%20Objectives \%20in\%20Syria.pdf

[10] Saradzhyan, S. (October 21, 2015) Russia's Interest in Syria is Not Assad. https://www.belfercenter.org/publication/russias-interest-syria-not-assad

[11] Kozhanov, N. (2018) Russian Policy across the Middle East: Motivations and Methods. Chatham House, London.

https://www.chathamhouse.org/sites/default/files/publications/research/2018-02-21 -russian-policy-middle-east-kozhanov.pdf

[12] Szénási, E. (2017) Syria: Another Dirty Pipeline War. International Security, 145, 188-204.

[13] Hill, F. (March 25, 2013) The Real Reason Putin Supports Assad. https://www.brookings.edu/opinions/the-real-reason-putin-supports-assad/

[14] Freire, M.R. and Heller, R. (2018) Russia's Power Politics in Ukraine and Syria: Status-seeking between Identity, Opportunity and costs. Europe-Asia Studies, 70, 1185-1212. https://doi.org/10.1080/09668136.2018.1521914 https://ezproxy.bue.edu.eg:2528/doi/pdf/10.1080/09668136.2018.1521914?needAcce $\underline{\text { ss}=\text { true }}$

[15] Techau, J. (September 8, 2015) A Russian Intervention in Syria? https://carnegieeurope.eu/strategiceurope/61218

[16] Mohseni, P. (2015) The Russian Intervention in Syria. In: Mohseni, P., Ed., Disrupting the Chessboard: Perspectives on the Russian Intervention in Syria, Belfer Center for Science and International Affairs, Cambridge, 1-7.

https://www.belfercenter.org/sites/default/files/legacy/files/Russia\%20in\%20Syria\% 20-\%20final\%20web\%202.pdf

[17] Tamaki, T. (2015) The Levels of Analysis of The International System. In: Encounters with World Affairs. An Introduction to International Relations, Ashgate Publishing, Farnham, 85-106.

https://dspace.lboro.ac.uk/dspace-jspui/bitstream/2134/17287/3/Tamaki\%20Ashgat e\%20Textbook\%20Chapter\%204\%20v2.0.pdf

[18] Otieno, A.A. (2008) Levels of Analysis and Foreign Policy. https://www.academia.edu/6623315/Levels_of_Analysis_and_Foreign_Policy

[19] Lemke, D. (1997) The Continuation of History: Power Transition Theory and the End of the Cold War. Journal of Peace Research, 34, 23-36.

https://doi.org/10.1177/0022343397034001003

https://www.jstor.org/stable/pdf/424828.pdf?refreqid=excelsior\%3Af94fb927f39ac2 7d9fc9c276aca34d91

[20] Kugler, J. and Organski, A. (2011) The Power Transition: A Retrospective and Prospective Evaluation. In: Handbook of War Studies, 171-194.

https://www.acsu.buffalo.edu/ fczagare/PSC\%20346/Kugler\%20and\%20Organski.p df

[21] Lebow, R.N. and Valentino, B. (2009) Lost in Transition: A Critical Analysis of Power Transition Theory. International Relations, 23, 389-410.

https://doi.org/10.1177/0047117809340481

https://pdfs.semanticscholar.org/f939/9c646e7bba29bb28dc7c4e1bef67b53dc223.pdf

[22] Garcia, H.A. (2018) Evolution of Russia Foreign Policy and the Middle East. JANUS.NET E-Journal of International Relations, 9, 103-121. https://doi.org/10.26619/1647-7251.9.1.7

[23] Luxmoore, M. (2014) Deffensive Imperialism: The Evolution of Russia's Regional 
Foregin Policy. International Journal on World Peace, New York, 21, 73-112. https://ezproxy.bue.edu.eg:2480/stable/pdf/24543801.pdf?ab_segments=0\%252Fdefa ult-2\%252Fcontrol\&refreqid=excelsior\%3A524818cad27880a5616d6f3699836b7d

[24] Oliker, O., Crane, K., Schwartz, L.H. and Yusupov, C. (2009) Russian Foreign Policy. In: Oliker, O., Crane, K., Schwartz, L.H. and Yusupov, C., Eds., Russian Foreign Policy: Sources and Implications, RAND Corporation, Santa Monica, 83-138. https://ezproxy.bue.edu.eg:2480/stable/pdf/10.7249/mg768af.11.pdf?ab_segments=0 \%252Fdefault-2\%252Fcontrol\&refreqid=excelsior\%3A018ab438115d04d8f0e524105 b03ec3a

[25] Mcfaul, M. (October 24, 2001) U.S.-Russia Relations after September 11, 2001. https://carnegieendowment.org/2001/10/24/u.s.-russia-relations-after-september-11 -2001-pub-840

[26] Hill, F. (August 15, 2002) The United States and Russia in Central Asia: Uzbekistan, Tajikistan, Afghanistan, Pakistan, and Iran.

https://www.brookings.edu/on-the-record/the-united-states-and-russia-in-central-a sia-uzbekistan-tajikistan-afghanistan-pakistan-and-iran/

[27] Ambrosio, T. (2005) The Russo-American Dispute over the Invasion of Iraq: International Status and the Role of. Europe-Asia Studies, 57, 1189-1210.

https://doi.org/10.1080/09668130500351357

https://ezproxy.bue.edu.eg:2480/stable/pdf/30043987.pdf?ab_segments=0\%2Fdefaul $\mathrm{t}-2 \% 2 \mathrm{Fcontrol} \&$ refreqid=search\%3A471d639b78f84b02ebe9d00d3e82d9f4

[28] Nation, R.C. (2007) Russia, the United States, and the Caucasus. https://press.armywarcollege.edu/cgi/viewcontent.cgi? article $=1692 \&$ context $=$ mono graphs

[29] Nichol, J. (March 3, 2009) Russia-Georgia Conflict in August 2008: Context and Implications for U.S. Interests. https://fas.org/sgp/crs/row/RL34618.pdf

[30] Bix, H.P. (2008) The Russo-Georgia War and the Challenge to American Global Dominance. The Asia-Pacific Journal, 6, Article ID: 2919. https://apijf.org/-Herbert-P--Bix/2919/article.pdf

[31] Graham, T. (December 10, 1999) U.S. Role in Chechnya. https://carnegieendowment.org/1999/12/10/u.s.-role-in-chechnya-pub-182

[32] Bagot, E. (2009) US Ambivalence and the Russo-Chechen Wars: Behind the Silence. https://www.semanticscholar.org/paper/US-Ambivalence-and-the-Russo-ChechenWars\%3A-Behind-Bagot/8e30be94851e607ad2fa48954e1df1d3ee77076f

[33] Trenin, D.V. (November 28, 2003) The Forgotten War: Chechnya and Russia's Future. https://carnegieendowment.org/files/Policybrief28.pdf

[34] Moga, T.L. and Alexeev, D. (2013) Post-Soviet States between Russia and the EU: Reviving Geopolitical Competition? A Dual Perspective. Connections: The Quarterly Journal, 13, 41-51. https://doi.org/10.11610/Connections.13.1.03 https://ezproxy.bue.edu.eg:2480/stable/pdf/26326349.pdf?ab_segments=0\%252Fdefa ult-2\%252Fcontrol\&refreqid=excelsior\%3A278796ef5b8f86d972f23ea8f91f37d1

[35] Valasek, T. (2008) What Does the War in Georgia Mean for EU Foreign Policy? https://www.cer.eu/sites/default/files/publications/attachments/pdf/2011/briefing_g eorgia_15aug08_tv-1136.pdf

[36] Sinkkonen, T. (2011) A Security Dilemma on the Boundary Line: An EU Perspective to Georgian-Russian Confrontation after the 2008 War. Southeast European and Black Sea Studies, 11, 265-278. https://doi.org/10.1080/14683857.2011.589152

[37] Francis, C. (2008) "Selective Affinities": The Reactions of the Council of Europe and the European Union to the Second Armed Conflict in Chechnya (1999-2006). Eu- 
rope-Asia Studies, 60, 317-338. https://doi.org/10.1080/09668130701820192

[38] Corneli, S.E. (1999) International Reactions to Massive Human Rights Violations: The Case of Chechnya. Europe-Asia Studies, 51, 85-100.

https://doi.org/10.1080/09668139999137

[39] Matsaberidze, D. (2015) Russia vs. EU/US through Georgia and Ukraine. Connections: The Quarterly Journal, 14, 77-86.

https://doi.org/10.11610/Connections.14.2.06

https://ezproxy.bue.edu.eg:2480/stable/pdf/26326399.pdf?ab_segments=0\%252Fdefa ult-2\%252Fcontrol\&refreqid=excelsior\%3A5e321000c23cc1006cfc6ce5accc9ff9

[40] Fakiolas, T.E. and Fakiolas, E.T. (2009) Domestic Sources of Russia's Resurgence as a Global Great Power. Journal of International and Area Studies, 16, 91-106. https://ezproxy.bue.edu.eg:2480/stable/pdf/43107193.pdf?ab_segments=0\%252Fdefa ult-2\%252Fcontrol\&refreqid=excelsior\%3A85e5aa68f8cd7aa742dcc9d35ef60375

[41] Popov, V. (2008) Resurgent Russian Economy? Putin's Policy without Putin? International Journal: Canada's Journal of Global Policy Analysis, 63, 247-261. https://doi.org/10.1177/002070200806300202 https://ezproxy.bue.edu.eg:2480/stable/pdf/40204360.pdf?ab_segments=0\%252Fdefa ult-2\%252Fcontrol\&refreqid=excelsior\%3A6b640c5c708507390b543992c91739c7

[42] Marples, D.R. (2008) Is the Russia-Belarus Union Obsolete? Problems of PostCommunism, 55, 25-35. https://doi.org/10.2753/PPC1075-8216550103

[43] Blinick, A. (2008) Pipeline Diplomacy: Russian Gas and Putin's Power. The New Atlantis, No. 21, 122-127.

https://ezproxy.bue.edu.eg:2480/stable/pdf/43152432.pdf?ab_segments=0\%252Fdefa ult-2\%252Fcontrol\&refreqid=excelsior\%3Ad302d50e987bc18881155becf665e2bc

[44] Pirani, S., Stern, J. and Yafimava, K. (2009) The Russo-Ukrainian Gas Dispute of January 2009: A Comprehensive Assessment. The Oxford Institute for Energy Studies, Oxford. https://doi.org/10.26889/9781901795851

https://www.oxfordenergy.org/wpcms/wp-content/uploads/2010/11/NG27-TheRuss oUkrainianGasDisputeofJanu-

ary2009AComprehensiveAssessment-JonathanSternSimonPiraniKatjaYafimava-200 9.pdf

[45] Forbrig, J. (2015) A Region Disunited? Central European Responses to the Russia-Ukraine Crisis.

https://www.dokumenty-iir.cz/Kratochvil/RegionDisunited_Feb15_web.pdf

[46] Goldman, M.I. (2009) Russia: A Petrostate in a Time of Worldwide Economic Recession and Political Turmoil.

https://www.jstor.org/stable/40972139?seq=1\#metadata_info_tab_contents

[47] Robinson, N. (2013) Russia's Response to Crisis: The Paradox of Success. Europe-Asia Studies, 65, 450-472. https://doi.org/10.1080/09668136.2013.779462

[48] Cohen, A. and Ericson, R. (2009) Russia's Economic Crisis and U.S.-Russia Relations: Troubled Times Ahead. https://www.heritage.org/node/13986/print-display

[49] Mankof, J. (2010) The Russian Economic Crisis. Council Special Report No. 53, Council on Foreign Relations.

https://www.voltairenet.org/IMG/pdf/Russian_Economic_Crisis.pdf

[50] Sutela, P. (July 29, 2010) Russia's Response to the Global Financial Crisis. https://carnegieendowment.org/files/russia_crisis.pdf

[51] Krijestorac, M. (2018) Imposing Particular Identities: The Balkans as a Meeting Place of Ethnicities and Religions. Insight Turkey, 20, 241-264.

https://doi.org/10.25253/99.2018203.10 
https://www.jstor.org/stable/26469854?read-now=1\&seq=7\#page_scan_tab_contents

[52] Kozhanov, N. (2017) Russian Foreign Policy in the Middle East: New Challenge for Western Interests? In: Meister, S. and Hamilton, D., Eds., The Russia File: Russia and the West in an Unordered World, Center for Transatlantic Relations, Washington DC, 101-125.

https://archive.transatlanticrelations.org/wp-content/uploads/2018/01/Russia_File.p df

[53] Popescu, N. and Secrieru, S. (2018) Russia's Return to the Middle East Building Sandcastles? https://www.iss.europa.eu/sites/default/files/EUISSFiles/CP_146.pdf

[54] Schneider, B.A. (2012) Russian Foreign Policy in the Middle East: Priorities and Effectiveness. Thesis, University of Denver, Denver.

https://digitalcommons.du.edu/cgi/viewcontent.cgi?article=1582\&context=etd

[55] Erdogan, S. (2015) Arab Uprisings and Russia’s International Standing.

[56] Katz, M.N. (April 3, 2012) Russia and the Arab Spring.

https://www.mei.edu/publications/russia-and-arab-spring

[57] Klein, M. (2012) Russia and the Arab Spring. https://www.swp-berlin.org/fileadmin/contents/products/comments/2012C03_kle.pdf

[58] Song, Y. (2016) The US Commitment to NATO in the Post-Cold War Period-A Case Study on Libya. Journal of Transatlantic Studies, 14, 83-113.

https://doi.org/10.1080/14794012.2015.1125165

[59] Russell, M. (2018) Russia in the Middle East From Sidelines to Centre Stage. https://www.europarl.europa.eu/RegData/etudes/BRIE/2018/630293/EPRS_BRI(201 8)630293_EN.pdf

[60] Krasna, J. (2018) Moscow on the Mediterranean: Russia and Israel's Relationship. https://www.fpri.org/wp-content/uploads/2018/06/krasna2018.pdf

[61] Unnikrishan, N. and Purushothaman, U. (2015) Trends in Russia-China Relations Implications for India.

https://www.orfonline.org/wp-content/uploads/2015/07/ORF_Monograph_Nandan Unnikrishanan.pdf

[62] Blasko, D.J. (2015) The 2015 Chinese Defense White Paper on Strategy in Perspective: Maritime Missions Require a Change in the PLA Mindset.

https://jamestown.org/program/the-2015-chinese-defense-white-paper-on-strategyin-perspective-maritime-missions-require-a-change-in-the-pla-mindset/

[63] Chatzky, A. and McBride, J. (2019) China’s Massive Belt and Road Initiative. https://www.cfr.org/backgrounder/chinas-massive-belt-and-road-initiative

[64] Hannah, J. and Adesnik, D. (2019) The Trump Administration's Foreign and National Security Policies.

https://www.fdd.org/wp-content/uploads/2019/01/fdd-report-trump-midterm-asses $\underline{\text { sment.pdf }}$ 